\title{
Buddhism in Christian State: \\ Competition in Buryat Spiritual Space in Late-Imperial Russia
}

\author{
Darima D. Amogolonova* \\ Institute for Mongolian, \\ Buddhist and Tibetan Studies SB RAS \\ 6 Sakhyanovoi Str., Ulan-Ude, 670047, Russia
}

Received 25.02.2017, received in revised form 02.11.2017, accepted 16.11.2017

The paper discusses the problems of correlation between religious and state-national identity on the example of Buryats in late-imperial Russia. Being the only state religion, Russian Orthodoxy suspected other religions and followers in lack of patriotism and loyalty. On their side, Buddhist clergy diligently proved their devotion to the Tsars and Russian state. The Buryat ethnocultural revival in the end of $19^{\text {th }}$ - beginning of $20^{\text {th }}$ century promoted politicization of Buddhism since the Buryat leaders considered religion as an instrument for consolidation. Nevertheless, neither Buryat leaders (and Buddhist priests among them) nor ordinary believers made plans on separation from Russia. Quite the contrary, the ideas about the right to self-determination and governing improvements focused on further existence of Buryats in the Empire and preservation of their cultural heritage including religious traditions.

Keywords: Orthodoxy, Buddhism, religious identity, Buryats, Russian Empire, spiritual space.

DOI: 10.17516/1997-1370-0184.

Research area: culturology.

\section{Introduction}

In most polyethnic and multicultural countries, the question of religious coexistence is always topical, largely independently how deeply the society is secularized. In this sense, the example of Buryatia where traditions of Russian Orthodoxy and Buryat Buddhism and shamanism met is quite revealing. Assessing the old history of relations between the Russian state and Buddhism in Buryatia, present-day Hambo Lama Damba Ayusheev expressed gratitude to the Russian monarchs beginning from Elizabeth and Catherine the Great, "for their kindness to the people of Transbaikalia and Eastern Siberia who followed the Buddhist Teaching". When receiving the Head of the Russian Imperial House, Her Imperial Highness the Grand Duchess Maria Romanov of Russia at the Ivolga Datsan, Hambo Lama Damba Ayusheev marked that "having legislated the rights of the Buddhist clergy, the Russian state created all conditions for the further development of Buddhism in Russia

(C) Siberian Federal University. All rights reserved

* Corresponding author E-mail address: amog@inbox.ru 
as well as the educational system of our region as a whole" (Anzhylova, 2014: 9). Recently the head of Orthodoxy in Buryatia Archbishop (Metropolitan) Savvatiy in the interview to the newspaper said that historically the Russian Orthodox Church and Buddhist traditional Sangha always coexisted peacefully, "we never competed and we did not have contradictions" (Tsyrenov, 2017: 3).

Such soft and pleasing characteristics of interreligious relations between Orthodoxy and Buddhism are aimed at present-day Russian society, in which the equality of religious communities and churches is guaranteed by a special Law. Notwithstanding, in the course of imperial history the competition between Orthodoxy and Buddhism in the Buryat spiritual space was determined by the dominance of Christianity that was the only state religion. Thus all the rest religions and communities though recognized, faced, alongside with mistrust, the baptizing policy that was, sometimes latently, approved by the state.

\section{Materials and Methods}

The research is based on the archival materials gathered in the Russian State Historical Archive and in the Orientalists' Archive at the Institute of Oriental Manuscripts (St. Petersburg). The sources can be grouped as a) state regulations, decisions and reports concerning Christianization of Buryats and the positions of Buddhism; b) mail correspondence between, on the one side, Irkutsk eparchy and Orthodox missions and, on the other side, Holy Synod and the Department of Foreign Religions at the Ministry for Home Affairs; and c) documents concerning Buddhism including letters, petitions and applications written by Buryats both clergy and laymen.

Methodology of the research is based on the totality of historical approaches with special focus on comparative, functional, and genetic aspects of the history and sociology of religion. Present-day concepts were born in the framework of various scientific disciplines and now coexist and mutually enrich each in social anthropology that proposes a number of basic ideas. Among them let's mark Fukuyama's explanation for the reason why religion occupies consistently stable position in the society. This is because of its social capital that is an inexhaustible need to unite and be united on the basis of the common belief and desire of people to live in accordance with the law. Better social responsibility of citizens is formulated deeper is the desire (Fukuyama, 1999). This statement is just both for traditional community that Buryats were in the $19^{\text {th }}$ beginning of $20^{\text {th }}$ century and nowadays because it highlights not religious belief but the social function of institutionalized religion i.e. religious organizations that guarantee preservation of social order including the state - exactly in this key I am researching the developments in the Buryat community before the October revolution.

Thus, the concept of adherence can or even should be considered from the point of social loyalty: "Faith can be seen, not so much as commitment, as the celebration of community. Affirmation of the supernatural is de-coded as expression of loyalty to a social order and its values. The doctrine de-coded along these lines is no longer haunted by doubt-for there isn't really any doctrine, only a membership, which for some reason employs doctrinal formulation as its token. The cosmogony of a given faith, in such softened modernist re-interpretations, is in effect treated not as literal truth, but merely as some kind of parable, conveying 'symbolic' truths" (Gellner, 1992: 3-4).

In the context of my research, especially important is considering religion as a system of symbols that "acts to establish powerful, pervasive, and long-lasting moods and motivations in men by formulating conceptions of 
a general order of existence" (Geertz, 1973: 90). In this sense, Orthodox intention to dominate in the territories inhabited by the indigenous ethnic groups of Siberia implied substitution of the traditional cultural symbols by the Russian ones that contained stereotypes of Russian political culture and thus promoted Russian homogeneity and loyalty.

\section{Results}

Religious identity as one of the numerous social identities takes an important position in the hierarchy of identities because of its consolidation and mobilization potential. Therefore in the course of the Empire, the Russian state and Orthodoxy considered baptism of Siberian natives (inorodets) as an important tool for strengthening state political positions and in addition promoted communion of non-Russians to the progressive values: "The concept of world history (universal chronology) and the unqualified support for the "moderns" over the "ancient" were recent imports from Germany, both crucial to Russia's state - sponsored 'growing-up' project. $<\ldots>$ the inozemtsy (literally: foreigners, here - natives. $D$.A.) were not only 'from a different land' but also from a different time. Infants must be baptized and taught how to write" (Slezkine, 1994: 47). Up to the first decades of the $19^{\text {th }}$ century, Buddhism seemed a backward pagan cult similar to various shamanic beliefs widespread among Buryats, Tunguses (now Evenks), Yakuts, and Chukchi. The Christianization of the adherents of different faiths including shamanists and Buddhists was aimed at the education of Russian identity that guaranteed loyalty to the monarchy and thus Russian patriotism. Besides Russification through Christianization and basic education in Russian, another aim could be attained: the rapprochement between ethnic Russians and indigenous people. This also worked for political objectives: “Hitherto for one non-Russian we haven't even two Russians, and for one unorthodox we can hardly count two Orthodox <..., territorial remoteness, in which unorthodox settlements are situated from the center of Russian life, not only naturally prevented the merger of non-Russians with the main population of the state but brings to the fact that local Russian population almost doesn't know the neighboring non-Russians" (Pozdneev: 2).

Christianization of Buryats - one of the biggest Siberian indigenous ethnic groups seemed a necessary tool for strengthening the borders of the Empire under threat from Qing China. Buryats at that time were divided into two sub-groups. Pre-Baikal (Western) Buryats were not embraced by Buddhism and remained shamanists. Christianization among them was quite successful at least formally. The situation with Trans-Baikal (Eastern) Buryats was quite different: largely, they were steadfast Buddhists, and Christianization among them was weak. Considering this fact, the state authorities built relationships with the Buddhist clergy in the framework of the existed legal regulations that took the most complete form in the "Regulations on the Lamaist clergy in Eastern Siberia" (1853) that was prohibitive in the sense of strict limitation of the number of monks-lamas and temples-datsans.

The Orthodoxy was irreconcilable towards Buddhism overall the whole imperial history and "to the end of the $19^{\text {th }}$ century, this opposition has extremely escalated" (Tsyrempilov, 2015: 40). The situation worsened at the end of the $19^{\text {th }}$ century, when in connection with the Buryat ethnonational movements Buddhism began to spread among Western Buryats causing serious trouble to the Irkutsk Orthodox eparchy. Failures in the baptizing policy were explained by the activities of the Buddhist clergy that enjoyed unlimited authority and influence among the Buryat population: 'Monks-lamas strongly 
frighten Buryats in making the Christian faith', 'Buryats for the most part very firmly hold their superstitions but not because of being convinced of their truth as they do not know the truths of their faith, but because they believe these superstitions are the legal faith of Mongols, and most of all because they are afraid of the lamas more than their authorities who act unanimously with the lamas. Lamas are so numerous and they are touring through the ulus (villages) so often that the aboriginals are in perfect enslavement at the lamas' (Otchet Irkutskogo episkopa...: 14, 26).

Meanwhile, the real root was of course the fact that the Orthodox clergy that persistently named Buddhism the paganism, for a long time did not want to understand the meaning of the Buddhist doctrine and faith. This significantly impeded figuring out the reasons why Buddhist influence was expanding on the both sides of lake Baikal, among long ago buddhicized eastern Buryats and western Buryats-shamanists who were steadily turning to Buddhism during the $19^{\text {th }}$ century. This process was marked with displeasure in the reports of the Irkutsk eparchy to the Holy Synod. As early as in 1841 Irkutsk archbishop Nil wrote: "Among Alarsky and Balaganskiy Buryats (western Buryats) there are many Christians. The number of these and general disposition of the tribes to spiritual enlightenment is increasing from year to year because the (Orthodox) clergy has the possibility to affect them with greater convenience than others $<\ldots>$. The dominant belief among them is Shamanism and its followers are much closer to Christianity then Buddhists. Unfortunately, the lamas from Transbaikalia began to sneak to them. And having been supported by the clan heads Taishas that are the everlasting enemies of Christianity - they are changing in the spirit of the tribes considerably" (Pis'mo Nila...: 5).

Consolidating and identification importance of Buddhism has become very noticeable from the last third of the $19^{\text {th }}$ century when the Buryat national movement got momentum for widening in connection with painful administrative reforms on the Buryat territories. Simultaneously the Orthodox Church also intensified its efforts to strengthen positions among Buryats. This was marked in particular with the cases of forcible baptism, which were numerous although only a few of them were documented in the petitions to the Irkutsk Governor-General. The complainers described cruelty and brutality of the officials who were dragging to the church the resisting people who did not want to betray their Buddhist religion, which was the main obstacle to the adoption of Orthodoxy: "they announced to me that I was to adopt Orthodoxy. As I confess the Buddhist religion (Lamaism), I did not want to neglect it. Seeing the insistence, I was forced to hide and really went into the taiga having left behind my pregnant wife" who was baptized forcibly in the church where she was dragged unconscious after beating (Prosheniya zhitelei Balaganskogo okruga...: 12).

In the 1890es, the growing number of baptized Buryats (whatever methods were used) resulted from the zeal of the officials to celebrate a significant event - a visit paid to the Buryat territories by the crown prince Nicholas in 1891. Perpetrators of forcible baptism argued that "all these were done upon wish and order of the Sovereign-Heir and therefore the complaints $<\ldots>$ will have no effect" (Prosheniya zhitelei Balaganskogo okruga...: 12).

At the same time, from the point of view of those who carried out the task of baptism, the converted natives did not become real Christians because "most of them knew Christianity only by the name" (Otchet Irkutskogo episkopa...: 12). Moreover, those Buryats who were empowered with governmental authority adopted baptism for career reasons but remained either Buddhists or shamanists in worldview respect. In his report to 
the Synod, the Irkutsk bishop in details explains that both the former Tunka Taisha and his son who became Taisha after his father received state awards for converting Buryats into Orthodoxy. However, both Taishas "hitherto not only by inner convince but also in outer appearance are the idolaters. When visiting his house consisting of two big rooms I saw in the anteroom the icon of St. Nicholas but in the second one, which is the main room I saw that the whole front wall was laden with sculptured and painted idols, some of which are depicted in exactly that form, in which the evil spirits are drown. $<\ldots>$ Old Taisha secretly feels even hostile feeling towards Christianity". When proposed to get rid of the "idols" giving them immediately to one of his sons who became a lama, a former Taisha "resolutely refused $<\ldots>$ and answered that he would never part with his idols-patrons" (Otchet Irkutskogo episkopa...: 13-14).

Suspicion towards alien religion forced the defenders of Orthodoxy to look for subversive elements in Buddhism. Of course, to achieve this aim it was necessary to get acquainted at least basically with the basics of doctrine; this was undertaken by some of the priests of the eparchy and the Orthodox missionaries. Looking for hostile sense implied not only the activities of the Buddhist clergy but also Buddhist soteriology. It is noteworthy that even those Russians, who lived near Buryats for a long time, watched their practical life and made efforts to understand the Buddhist culture, also were looking for accusatory malicious content of the Buddhist sermons and prayers. For example, the Irkutsk priest Innokentiy Podgorbunsky known for his exceptional knowledge of Buryats and the author of numerous works on Buddhism and shamanism harshly criticized the prayers composed by Hambo Lama Gomboev for the longevity and prosperity of the Romanovs' dynasty. In 1891, Podgorbunsky expressed his arguments in the
"Irkutsk Eparchial Gazette" concerning the question whether the head of the Buryat Buddhists possessed sincere religious feelings and Russian patriotism: "Buddhists are still praying for what in their doctrine is the highest good, i.e. they are praying for the better reincarnation that would put them on the path to Nirvana, that is non-existence or, at least, unconscious being and for achievement of proper Nirvana. Dampil Gomboevich, on the contrary, is praying with the aim the Supreme God Buddha and the Almighty God, the giver of immortality, gave the Sovereign Emperor and Heir-Tsarevich a longstanding life, i.e., he is praying exactly for the aim that from the Buddhist point of view is considered the greatest misfortune. Thus, this brings to one of two conclusions: "either the author of prayer wishes the greatest misfortune to the Emperor and HeirTsarevich under the guise of happiness or denies most basic teachings of Buddhism for something else that consciously is his personal life, and asks the Buddha to give him what The Buddha didn't allow to ask for. $\langle\ldots>$ To wish the Nirvana to the Tsar-Emperor is of course inconvenient and indecent. Meanwhile, because of certain goals it was necessary to attract attention to the Hambo lama and to the entire corporation of lamas as patriots. And the head of the Buryat Buddhism who is obliged to take care of its integrity is the first who sacrifices his religion to some selfish calculations" (Arhiv Ts.Zh. Zhamtsarano: 208209).

Such a demagogic expedient in relation to the realities of cultural interaction drew criticism even from the newspaper-journal on literature and politics "Citizen" that was famous for its extreme monarchism. In the publication "About rudeness and tactlessness of the Eparchial Gazette", Podgorbunsky's speech was called the most daring and the most flagrant manifestation of "on the one hand, ignorance and, on the other hand, irrational intolerance beyond all bounds". 
The "Citizen" reinforces its point of view with the evidence of Buryats' loyalty to the Empire. In modern terms, it was about the undoubted Russian identity of the Buryat Buddhists expressed in adoration and deification of the royal persons by the broad masses of Buryats that was proved in particular by the fact that when the Heir Nicholas journeyed through the Buryat territories "where for many days He was surrounded by the crowds of Buddhists", the Buryats were his coachmen and he was guarded by the Buryats-riders and "hundreds of Buryats rushed to the Tsarevich's carriage and not daring to touch Him took sand from the wheels and carried away kissing as a holy thing. $<\ldots>$ And these Buddhists or Buryats were praying for the safe journey of the Heir to the Russian throne and sincerity of their prayers was rather confirmed by the sincerity of all manifestations of not only order, not only loyalty but also adoration" (Arhiv Ts.Zh. Zhamtsarano: 206-208).

The undeniable Russian identity of the Buryats is also proved by the desire and tempos they mastered the Russian language as well as execution of the most important political function on protecting imperial borders that was fulfilled by the Buryats-Cossacks. The Ts. Zhamtsarano's Archive contains abstracts from the article in the St. Petersburg's "Official Gazette" for 1892, which shows a picture of how the Buddhist religion contributed to the education of Russian patriotism among Buryats. Also, the newspaper argues that the "militant Buddhism does not exist among our lamas and it is even less encouraged at public expense" and further names the notable and active russification of Buryats as "unsophisticated and naturally rational". The Buryats, the newspaper says, are "not inert and anti-cultural mass but the conductors of Russian influence in Central Asia, unshakably loyal servants of the deified by them White Tsar, and exemplary performers of civic duties". Buddhist relation to Orthodoxy is described in positive colors: "the missionary churches in Eastern Siberia are supported by Buryat pagans who attend Orthodox churches and learn Christian prayers"; this shows that the Buryat Buddhist "are people of unusual tolerance". When comparing Buryats with Kalmyks - other followers of Buddhism in Russia - the newspaper marked that the Buryats have reached a higher level of loyalty to the Russian state: "If we compare the conditions of the East Siberian Buddhists with those in which our European Kalmyks are, the latter will be in much more favorable conditions. But the degree of russification among Kalmyks is much lower than this in the Baikal territories. Meanwhile, nothing is written about this though Kalmyks live in only three-day travel from Moscow” (Arhiv Ts.Zh. Zhamtsarano: 211).

In any case, the Russian authorities thought that Russification was the way to Christianization. So, Buddhism was to be treated as a temporary stage that would be overcome in not a distant future. And until Buddhism doesn't harm the Russian identity of the Buryats ("You can see: they are more honest and loyal then thousands of the Orthodox only by name") this religion can be allowed. Simultaneously, pressure on Buddhism was to increase as Amur GovernorGeneral baron Andrei Korf proposed in his letter to the Government entitled "On facilitating spread of Christianity in Trans-Baikalia”: to intensify primary education among Transbaikalian Buryats "as a measure that is most useful for rapprochement of Buryats with the Russian population. For this purpose it is highly desirable to recognize to open as many as possible public schools in the Trans-Baikal region"; to improve on the structure of missions and to arrange well the missionary churches. Also Korf proposed to change some conditions of religious rites because the existed ones prevented "the pagans to take holy baptism" (Zhurnal osobogo soveshaniya...: 4-5). 
Meanwhile, the clear-headed opponents of Buddhism began to understand that Christian preaching and baptism policy could not bring to the desired results. To be successful it was necessary to recognize that in the case of Buddhism they deal with ancient and highly rationalized worldview, which can withstand strong pressure. To put forward the arguments in favor of Christianity, the Orthodox preachers were to come closer to the culture of the natives: "Coming to the pagans, the servants of Christ made every effort to educate them with the light of the Gospel teachings; but what could they do, especially lacking knowledge about language, beliefs and way of life of the inorodets? Some of the fathers-missionaries at the age of 30 and 40 began to study languages. However, having no manuals and research studies they were guided only by their personal experience and comprehension; they unwittingly made up onesided and often completely perverse ideas about both separate words and integer expressions and this was so sad that the aforementioned onesidedness related not to everyday objects but namely the notions relating to metaphysical and transcendental concepts. From time immemorial, two outstanding by their number ethic groups attracted the attention of pastors of our Church; in general, we call these ethnic groups Tatar, professing Islam, and Mongolian, devoted to the faith of the Buddha; and among both peoples our activities at first seemed quite the same" (Pozdneev: 2-3).

Being an outstanding Mongolist, A.M. Pozdneev nevertheless by all means directed the missionaries to struggle against Buddhism. For this purpose he proposed a strategic plan aimed, first, at mastering the culture of aliens, and then, second, the gradual penetration into their minds the idea of superiority of Christianity over Buddhism. Having no knowledge of other religion it is impossible to resist such, for example, judgment expressed by the head of the Kuytinski inorodets department Tsyaryan Tuhaev in response to the accusation that despite a high official position he did not accept Orthodoxy: "because my religion teaches to love our neighbor, to do good, to tell the truth, not to slander and so on" (Pis'mo Glavy...: 11-12).

Thus, regardless the ultimate aim, Alexei Pozdneev encourages the students of the Missionary Institute to master Buryat culture and to achieve mutual understanding and trust between Christians and Buddhists. To do this, A. Pozdneev advised the young missionaries to make every effort to become high professionals possessing in-depth knowledge that would help to convince non-Christians to reject their beliefs. The Missionary Institute had to respond to such demands, namely "putting his aim as training those who will spread the Gospel teaching among the inorodets who speak Mongolian, the Missionary Institute should give its students the opportunity $<\ldots>$ to acquire both theoretical and practical knowledge of the language of inorodets" (Pozdneev: 2-3).

As for Buddhism, "the subject of their future struggles", to explain "the failure of its doctrine", Alexei Pozdneev advised to study not Buddhism in general but specifically that its form, which was common among the Buryats. In other words, the scholar proposed to study Buryat religiosity considering the realities of the Buryat folk Buddhism. Recognizing a really existing difference of the Buryat Buddhist cultural complex from the other ones, mainly in the field of rituals, Alexei Pozdneev points to the need not only to get acquainted with the dogmatic foundations but also with the entire set of specific religious beliefs and practices that form the ethnic cosmology and, most importantly, the political conception on world order. Appealing to study the religious culture of others, A. Pozdneev meant first to reconcile ethnocultural communities and 
then achieve religious homogenization, by which he meant Orthodoxy - the stronghold of Russian identity.

The Orthodoxy on its side sought to narrow the social base of Buddhism by increasing the number of baptized Buryats. The failure of this activity resulted from a number of reasons: firstly, the missionaries did not speak the Buryat language and therefore had to resort to translators who were ordinary people who could not convey "the most original truths of faith". To overcome this difficulty in communication between missionaries and Buryats, the Irkutsk bishop Eusebius offered to select seven or eight young people who received higher or secondary education in the seminary, as well as children from the families of baptized Buryats, in order they get full missionary and university education in the Mongolian language. Secondly, the missionaries could not convincingly convey the advantages of Christian soteriology in comparison with Buddhism because they had no idea of the Buddhist path and Buddhist conceptual apparatus, and therefore they were not able to preach among the Buryat Buddhists in the terms of their religion. Irkutsk bishop Parthenius appointed in 1860 immediately embarked on a difficult journey around the eparchy including its remote parts. Parthenius not only inspected the missionary camps (he was extremely dissatisfied with their work) and gathered information on the number of newly baptized non-Russians but also tried to learn what Buryats thought about Christianity and how the enemies of Christianity express their opposition. Besides, his journey focused on "looking for people both Christians and non-Christians who could be helpful in converting Buryats to Christianity". "For better control over natives" and for better contact with Buddhists, Parthenius invited a missionary archpriest Dorontev who was a Buryat and former Buddhist lama. The latter managed to make a missionary preaching successful: "he undertook several very big trips $<\ldots>$ in order to collect data about natives in relation to their disposition to Christianity <..>; in the course of one year he turned to Christ more than 50 people and collected some data useful for establishing new missions" (Otchet Irkutskogo episkopa...: 25, 51).

Buryats' attachment to Buddhism was also connected with the emerging ethnocultural and ethnonational identity. Nikolai Tsyrempilov marks the reason why the Buryat Buddhist community was sustainable: "As a matter of fact, the Buryat ethnic identity actualized within the system of Buddhist monastic parishes while the tribal bodies of self management, in contrast, divided people by clan lines. Being a part of the empire, in which Orthodox Christianity occupied absolute dominant position, Buryats saw in Buddhism the most powerful core, around which they could mobilize their ethnic identity" (Tsyrempilov, 2013: 196).

At the same time, in spite of the very painful process of formation and consolidation of the Buddhist community in times of restrictive laws, the institutionalized Buddhism in Buryatia always sought to show and prove its loyalty to the Empire and brought in its followers a sense of loyalty to the monarchy and Russian state. Thus, the Buddhist religious identity became inseparable from the Russian identity. At the same time one should take into consideration the idea about cultural space, according to which the Orthodox Church is the religion of Russians while Buddhism is the religion of Buryats. Religion promotes strengthening ethnic identity that provides not only the translation of traditions from generation to generation but also a sense of personal security. It is worth mentioning that rapprochement of Buryats with the Russians by means of Christianization and knowledge of Russian, European education, 
Russian model in everyday life for example wearing European clothes did not guarantee social equality. Orientalist Bazar Baradin during the expedition to Transbaikalia on behalf of the Russian Committee in 1904 put down in his diary one story that illustrates the attitude of the ethnic majority toward non-Russians. Together with his group equipped with a photo camera, in the hotel he faced the "concern" of several Russian officers because "by our appearance we were not similar to ordinary Buryats $\langle\ldots>$ Also they were much surprised with the absence of kowtowing to them from our side as usually they used to expect from almost every Buryat they meet. <...> Of course, we would have no difficulty to calm them down, but we didn't do this because of feeling of resentment that even such intelligent Russian people cannot look at Buryats slightly wider and nicer" (Zhamsueva, 2013: 83).

At first sight, this episode that reflects the overall picture of the relation of ethnic and cultural majority to the minority in the Russian Empire is not directly related to the issue of religious identity. However, it explains the reasons for politicization of the Buddhist religion in the period of the Buryat revival at the end of the $19^{\text {th }}$ century when the ethnonational leaders used Buryat cultural heritage in the aims of Buryat consolidation and education of ethnonational spirit.

\section{Conclusion}

The rapprochement between the Orthodox and Buddhist communities in Buryatia has been taking place at the popular level for a long period of history and eventually led to a peculiar religious syncretism in Buryatia. Different and distant Abrahamic and Dharmic religions coexist in the folk representations although mainly at the level of religious rites and holidays. However, there is a deeper worldview connection. On the one hand, the Buryats are the most russified and for this reason culturally Christianized non-Russian ethnic group in Siberia. On the other hand, the territorial cultural text consists of interweaved traditions of Orthodoxy, Buddhism, shamanism and Old Belief thus creating the regional identity that is the closest to the residents of Buryatia component of the Russian identity. It is important that in today's Russia, although the law specially marks Orthodoxy, the principle of equality of religions is observed and this plays an important role in maintaining stability and interethnic peace. In Buryatia where majority of the population is nominally Orthodox, humanitarian and geographic image of the space is defined by the traditions of Buddhism and shamanism. The Orthodox Church reacts to this by rapid increase of its official status in Buryatia from the part of Irkutsk eparchy to Buryat and Ulan-Ude Metropolis.

Along with the worldview function, both churches are performing the most important social functions, among which invariably present support to the state and demonstration of loyalty to the authorities. Of course, religious competition still exists and now this is due to the new economic conditions, which make the churches to fight for the flock. However, this competition does not infringe the rights and interests of churches and religious communities. The secular state copes with the task of observing the principle of equality of religions.

\section{References}

Anzhylova, D. (2014). Istoriya dlinoyu v 250 let [History of 250 years long]. In Argumenty i Fakty $v$ Buryatii. No. 31. P. 9.

Arhiv Ts.Zh. Zhamtsarano [Ts.Zh. Zhamtsarano's Archive. Papers and Fragments of papers]. In Arhiv vostokovedov IVR RAN. Fond 62, op. 1, d. 114. 
Fukuyama, F. (1999). The Great Disruption: Human Nature and the Reconstitution of Social Order. NY: Free Press. 354 p.

Geertz, C. (1973). The Interpretation of Cultures. Selected essays. New York: Basic Books, Inc., Publishers. $470 \mathrm{p}$.

Gellner, E. (1992). Postmodernism, reason and religion. London: Routledge. 108 p.

Otchet Irkutskogo episkopa o sostoyanii Irkutskoi Eparhii za 1861g. s dannymi o deyatel'nosti missionerov [Report of the Irkutsk bishop on the state of Irkutsk Eparchy for 1861]. In RGIA (Russian State Historical Archives). F. 796, op. 442, d. 51.

Pis'mo Glavy Kuitinskogo inorodcheskogo vedomstva Cyaryana Tuhaeva. Materialy iz arhiva E.E. Uhtomskogo [The letter written by the head of the Kuytinski inorodets department Tsyaryan Tuhaev. E. Uhtomski's Archives]. In Arhiv vostokovedov IVR RAN. Razryad III, op. 1, d. 13.

Pis'mo Nila, arhiepiskopa Irkutskogo, Svyateishemu Pravitel'stvuyushemu Sinodu ot 26 marta 1840g. [Irkutsk Archbishop Nil's Letter to the Holy Synod. March 26, 1840]. In RGIA, F. 796, op. 110, d. 805 .

Pozdneev, A.M. Zapiska o deyatel'nosti Missionerskogo Instituta pri Moskovskom Pokrovskom Monastyre. 4 oktyabrya $1895 \mathrm{~g}$. [Notes on the activities of the Missionary Institute at the Moscow Monastery of Protection of the Most Holy Mother of God]. In Arhiv vostokovedov IVR RAN. Fond A.M. Pozdneeva, F. 44, op. 1, d. 125.

Prosheniya zhitelei Balaganskogo okruga Irkutskomu general-gubernatoru s opisaniem proizvedennogo nad nimi nasil'stvennogo kresheniya i pros'bami o naznachenii rassledovaniya i privlecheniya vinovnyh $\mathrm{k}$ otvetstvennosti. Nachato 1891. [The petitions of the Balagansk District residents to the Irkutsk Governor-General with description of perpetrated forcible baptism. Started 1891]. In RGIA, F. 797, op. 96, d. 103.

Slezkine Yu. (1994). Arctic Mirrors. Russia and the Small Peoples of the North. Ithaca \& London: Cornell Univ. Press. 456 p.

Tsyrempilov, N.V. (2013). Buddizm i imperiya. Buryatskaya buddiiskaya obshina v Rossii (XVIIInach. XX v.) [Buddhism and the Empire. Buryat Buddhist Community in Russia (18 $8^{\text {th }}$ - beginning of $20^{\text {th }}$ century]. Ulan-Ude: IMBT SO RAN. 338 p.

Tsyrempilov, N.V. (2015). Gosudarstvo $i$ buryatskaya buddiiskaya obshina v Rossiiskoi imperii XVIII - nachala XX v. [The State and Buryat Buddhist Community in the Russian Empire of XVIII - beginning of the $20^{\text {th }}$ century. Synopsis of the thesis]. Diss. na soisk. uch. st. d-ra ist. $n$. Ulan-Ude, 2015. 431p.

Tsyrenov, M. (2017). Chelovek obretaet sebya [A man finds himself]. In Argumenty i Fakty v Buryatii. No. 3. P. 3.

Zhamsueva, D.S. (2013). (podg. k publ., predisl., komment., ukazatel'). Dnevnik vol'noslushatelya Sankt-Peterburgskogo universiteta Bazara Baradina po buryatskim dacanam (1903-1904 gg.) [St. Petersburg University extern Bazaar Baradin's Diaries on the Buryat Datsans (1903-1904)]. Ulan-Ude: Izd-vo BNC SO RAN. 237 p.

Zhurnal osobogo soveshaniya o merah k oblegcheniyu hristianskoi propovedi v Zabaikal'e [Special meeting protocol "On facilitating spread of Christianity in Trans-Baikalia"]. In RGIA, F. 797, op. 62 (2otd., 3 st.), d. 300. 


\title{
Буддизм в христианском государстве: \\ конкуренция в бурятском духовном пространстве \\ в позднеимперский период
}

\author{
Д.Д. Амоголонова \\ Институт монголоведения, буддологии \\ и тибетологии СО РАН \\ Россия, 670047, Улан-Удэ, ул. Сахьяновой, 6
}

\begin{abstract}
В статье исследуются проблемы соотношения религиозной и национально- государственной идентичности на примере бурят в позднеимперский период истории России. Русская православная церковь, представлявшая единственную государственную религию, полагала, что прочие религии и их последователи не обладают достаточным патриотизмом и лояльностью $\kappa$ государству. Между тем на протяжении всей имперской истории буддийское духовенство доказывало преданность российских буддистов иарям и России. Лидеры бурятского этнокультурного возрождения кониа XIX-начала XX века способствовали политизации буддизма, избрав его в качестве важнейшего инструмента этнокультурной консолидации бурят; с этой иелью институализированный буддизм принимал участие в пропаганде среди западных бурят-шаманистов. Однако при этом ни бурятские лидеры (в том числе и священнослужители), ни рядовые верующие не строили планов об отделении от России. Напротив, идеи о праве на самоопределение и усовершенствовании административного управления бурятскими территориями подразумевали дальнейщее существование бурят в Российской империи, сохранение их этнонациональной идентичности и культурного наследия вместе с религиозными традициями и при этом все большее включение в сочиально-экономическую, политическую и культурную жизнь страны.
\end{abstract}

Ключевые слова: православие, буддизм, религиозная идентичность, буряты, Российская империя, духовное пространство.

Научная специальность: 24.00.00 - культурология. 